\title{
Communication \\ Unawareness and Theorizing in Modern Geology: Two Examples Based on Citation Analysis
}

\author{
Dmitry A. Ruban 1,2 \\ 1 K.G. Razumovsky Moscow State University of Technologies and Management (the First Cossack University), \\ Zemlyanoy Val Street 73, 109004 Moscow, Russia; ruban-d@mail.ru \\ 2 Southern Federal University, 23-ja Linija Street 43, 344019 Rostov-on-Don, Russia
}

Received: 22 April 2020; Accepted: 28 May 2020; Published: 30 May 2020

\begin{abstract}
Progress in science is significantly influenced by the treatment of information generated by the international research community. A relevant problem is the unawareness of scientists regarding more widely published works and ideas. This problem is illustrated with two examples from geological studies. In the first case, the citation analysis implies that many geologists still use outdated reconstructions regarding eustasy for the Mesozoic-Cenozoic, and important updates are missed. This erroneous practice leads to the accumulation of questionable regional interpretations. In the second case, it is found that studies in which the end-Pleistocene extraterrestrial impact hypothesis was first proposed are cited more prolifically than contrary studies using arguments against this hypothesis.A kind of 'abandonment' of this still debatable but potentially important hypothesis also is found. The root cause behind such a patterns of unawareness by the research community is explained by insufficient attention being paid by today's geologists to critical literature reviewing, the rare use of bibliometric approaches, and, more generally, limited theorizing (especially in comparison to social sciences). A shift to full-scale theoretical geology is proposed, which would also help to minimize any negative consequences brought on by unawareness of a more global information base.
\end{abstract}

Keywords: bibliometry; eustatic curves; knowledge gaps; Pleistocene event; theoretical solutions

\section{Introduction}

Advancement in science depends strongly on the characteristics of international, national, and institutional research communities. Philosophers have described this dependence within the framework of the social determination of scientific cognition and progress [1-5], but its appearance in particular sciences and the solution of particular problems is yet to be fully understood. Technological advances facilitate information distribution among scientists, but the overwhelming scale of new information is, itself, a major challenge. The personal characteristics of researchers and socio-economic factors (e.g., state funding of libraries and Internet availability) influence how the research communities treat information. The links between researcher and research in such a specific and a somewhat 'marginal' science as geology (no longer taught in secondary schools, somewhat less popularized, and not yielding broadly discussed findings as in medicine or physics) remain almost unknown. It would be difficult to rule out the role of research community attitudes, beliefs, misconceptions, perceptions, and values in the progress of modern geology, which deals with multiple objects of study and is often based on subjective judgments and observations.

One of the biggest problems in the development of modern geology is linked to an apparent insufficiency of awareness regarding the wider geological research community. For instance, the geologic time scale has been significantly improved and refined since the mid-1970s, with significant progress after 2000 [6]. However, outdated stratigraphical information persists in the geological literature, including textbooks [7]. When mass extinctions and their potential causes are discussed (e.g., 
extraterrestrial impact versus volcanism as the main cause of the end-Cretaceous catastrophe [8-14]), the research community is only polarized and the normal mechanisms of hypothesis acceptance/rejection function with serious difficulties [15]. Many geoscientists concentrate on fact collecting and the application of 'high-tech' (e.g., geochemical) approaches. They follow only some developments by other specialists. At least in part, this situation accounts for the above-mentioned issues with the geologic time scale and the debate over causes of mass extinctions. However, these considerations are preliminary and highly subjective. As such, perceived levels of unawareness need to be documented properly in order for more definite and objective judgments to be made. In particular, citation analysis of some key fields of study can help to understand the degree to which geologists are aware of big ideas.

The objective of the present paper is to document the unawareness of the international geological research community based on two examples that seem to be representative. The first deals with the usage of global eustatic reconstructions-a previous study argued that many researchers applying 'classical' models are not aware of their updates and alternatives [16]. The second case relates the end-Pleistocene extraterrestrial impact hypothesis, which has been debated for more than a decade without reaching any consensus [17]. Both examples are related to subjects that are debatable (often hotly debatable) in leading international journals. A comprehensive study of citations on these topics in such journals promises to register the relevant unawareness of the international geological research community and to the roots of this unawareness. These examples permit a tentative insight into the extent to which multiple interpretations linked to the eustatic mechanisms and the end-Pleistocene events are correct. Moreover, the results of citation analysis of key articles allow the role of theorizing in the modern geology to be addressed.

\section{General Methodological Remarks}

The problem of unawareness in the geological research community can be approached differently-for instance, in the light of philosophical knowledge or by the use of sociological methodology. Each can clarify any particular aspect of this problem. Bibliometry entails a set of powerful techniques permitting the examination of various trends in science development with indicators linked to the level of publishing activity by researchers. Its fundamentals, approaches, perspectives, limitations, and applications were explained, particularly, in papers by Franssen and Wouters [18], Gerdel [19], Giske [20], Motoyama and Eisler [21], and Prashar and Sunder [22]. In the present paper, a simple bibliometric analysis is preferred for a sharp, quantitative illustration of the above-mentioned problem. Herein, attention is focused on citations to some landmark works in modern geology.

In the present treatment, all information on citations is taken from the major online bibliographical database 'Scopus'. On the one hand, this database includes articles from all top international journals on geology and many national and local editions (including those published in languages other than English). Currently, the number of the Earth and planetary sciences editions included in this massive database exceeds 2000. Importantly, the lists of references available in these articles are also included in the database, which allows for tracking the citations of the earlier-published works. Although 'Scopus' does not escape certain biases and incompleteness (no bibliographical database can escape them), it provides a truly comprehensive baseline for various kinds of bibliometric analyses. One only needs to take into account that this database better covers studies published since the mid-2000s than earlier publications. Notably, this database offers user-friendly analytical panels. All information on citations of the particular works survey in this study was collected in mid-April 2020.

The analytical procedures in this treatment are described as follows. In the first case, the level of awareness by geologists regarding updates of highly important studies is examined. For this purpose, the dynamics of citations of the original and updating works are compared. Unawareness can be recognized where the number of citations of the updating work remains significantly lower than that of the original work, especially if this is registered for five and more years. In the second case, the geologists' awareness of rejection of a highly challenging hypothesis is examined. For this 
purpose, the dynamics of citations of the hypothesis proposal and those studies that favor rejection are compared. Unawareness can be recognized where the number of citations of the rejection work remains significantly lower than that of studies favoring rejection. More detailed methodological information (chosen works, citation counting, comparison of citations, etc.) is provided separately, in each example considered below (this solution challenges the standard structure of a scientific work, but it permits making the latter more logical).

Undoubtedly, the context of citations (i.e., their meaning) can be very different. In some cases, studies are cited in the following papers only for historical and general (quasi-theoretical) purposes of reference. In the other cases, earlier developments can be used as 'standards' in later studies (for instance, when global 'standards' need to be applied for deciphering regional patterns). Addressing these issues would be important, but this is very challenging (if possible) due to the huge amount and partial availability of the literature sources. After the removal of these cases, more in depth analyses involving the content of the cited and citing works remain for further investigations. This study has a focus on the general citation dynamics that show a general awareness of the geological research community of the published works, irrespective of how this awareness affects current research. Anyway, the possible influence of the factor of the citation context is taken into account when the results are interpreted.

\section{Case A: Eustatic Reconstructions}

Since the end of the 1970s, significant advances in the understanding of the past global sea-level (eustatic) changes have been made. In addition to the 'pure' theoretical importance of this knowledge, the latter is necessary to decipher controls of basin-scale stratigraphical architecture to solve some practical tasks, including hydrocarbon exploration. The rise of sequence stratigraphy could not be possible without the noted advance. Progress in understanding eustasy has not been 'linear'. In contrast, it is marked by several 'splashes' and outstanding achievements. The most important was the publication of the detailed Mesozoic-Cenozoic eustatic curve at the end of the 1980s by Haq et al. [23,24]. This reconstruction has remained a reference for numerous global, regional, and local studies. Correspondence of basin-scale sea-level changes to those depicted on this curve is regarded as evidence of the prevalence of global control on regional sedimentation, whereas the absence of such a correspondence favors the prevalence of local tectonic activity and changes in accommodation space.

During the more than 30 years after the publication of the 'classical' reconstructions by Haq et al. [23,24], the two principal works by these specialists have accumulated a total of $>7000$ citations, which is almost unprecedented for geological articles. However, this does not mean such reconstructions represent 'final' developments. In contrast, some different, even alternative reconstructions have been proposed [25-33]. Moreover, Haq and his co-workers themselves updated their reconstructions, i.e., they have improved the knowledge of duration and magnitude of global sea-level changes, extended their curves to the Paleozoic, and employed refined geologic time scales. In the mid-2000s, Haq and Al-Qahtani [34] developed the Phanerozoic sea-level curve for Arabia and proposed a new global curve. A bit later, Haq and Schutter [35] re-worked the Paleozoic eustatic reconstruction. Thus, anew 'splash' occurred in the mid-2010s. In 2014, Haq [36] presented the updated Cretaceous reconstruction, followed by his updates for the Jurassic [37] and the Triassic [38]. In order to consult the most current version of the entire Phanerozoic eustatic curve, modern geologists need to consider several works, namely [35] for the Paleozoic, [38] for the Triassic, [37] for the Jurassic, [36] for the Cretaceous, and a part of the 'old' curve [34] for the Cenozoic. The 'classical' reconstructions [23,24] are no longer valid.

Even so, may geologists still refer to the 'classical' reconstructions of Haq et al. [23,24] without considering their updates. This represents a pattern of research community unawareness. The question under consideration is the degree unawareness and, thus, its influence on modern science. To evaluate the degree of observed unawareness, citation dynamics are analyzed for each 'classical' work [23,24] and each updating work [34-38]. The number of the relevant citations is counted for all years since 
1987 when the first 'classical' work [23] was published. For better clarity, several specific parameters are considered, namely S1 (the sum of citations of two 'classical' works), S2 (the sum of citations of the updating works dealing with the Mesozoic-Cenozoic interval [34,36-38]), S3 (S2 corrected in regard to the Paleozoic-see below), PZ5 (the corrected number of citations of [34]), and PZ8 (the number of citations of [35]). Corrections concerning the Paleozoic are necessary because the 'classical' reconstructions $[23,24]$ deal with only the Mesozoic-Cenozoic interval, whereas the first updating paper [34] deals with the entire Phanerozoic. If so, a part of citations of the latter cannot be considered as the evidence of awareness concerning the update of the previous version of the curve. Taking this into account, the number of citations of [34] is diminished tentatively by a factor of two (hypothetically, half of citations can be linked to the Paleozoic counterpart of the curve) for calculating S3 and PZ5.

The results of the citation analysis are as follows. The number of citations of the 'classical' articles by Haq et al. [23,24] rose significantly in the first half of the 1990s (Figure 1). Thereafter, one article [23] remained highly citable, and the other article [24] began to 'lose' citations. The dichotomy can be easily explained by the greater popularity of the former because of its appearance in 'Science' (a high-impact and high-prestige journal). Anyway, both articles received dozens of citations annually during the end-2010s. The article by Haq and Al-Qahtani [34] has attracted a relatively small number of citations, although this number has tended to increase (Figure 1). The summaries by Haq and Schutter [35] and Haq [36] have become more successful, and a judgement about the two latest papers [37,38] is too early because these remain very 'fresh'. However, those articles updating the Mesozoic-Cenozoic eustatic reconstructions [34,36-38] have not reached the citation level of the original articles (Figure 2). The situation is reversed regarding Paleozoic developments because the paper by Haq and Schutter [35] has been cited significantly more actively than the previous paper by Haq and Al-Qahtani [34] (Figure 3). Most probably, this is explained by the fact the latter appeared in a less-known journal, and this paper has been perceived (partly erroneously) by geologists as mainly a synthesis of the sea-level data on the Arabian Plate.

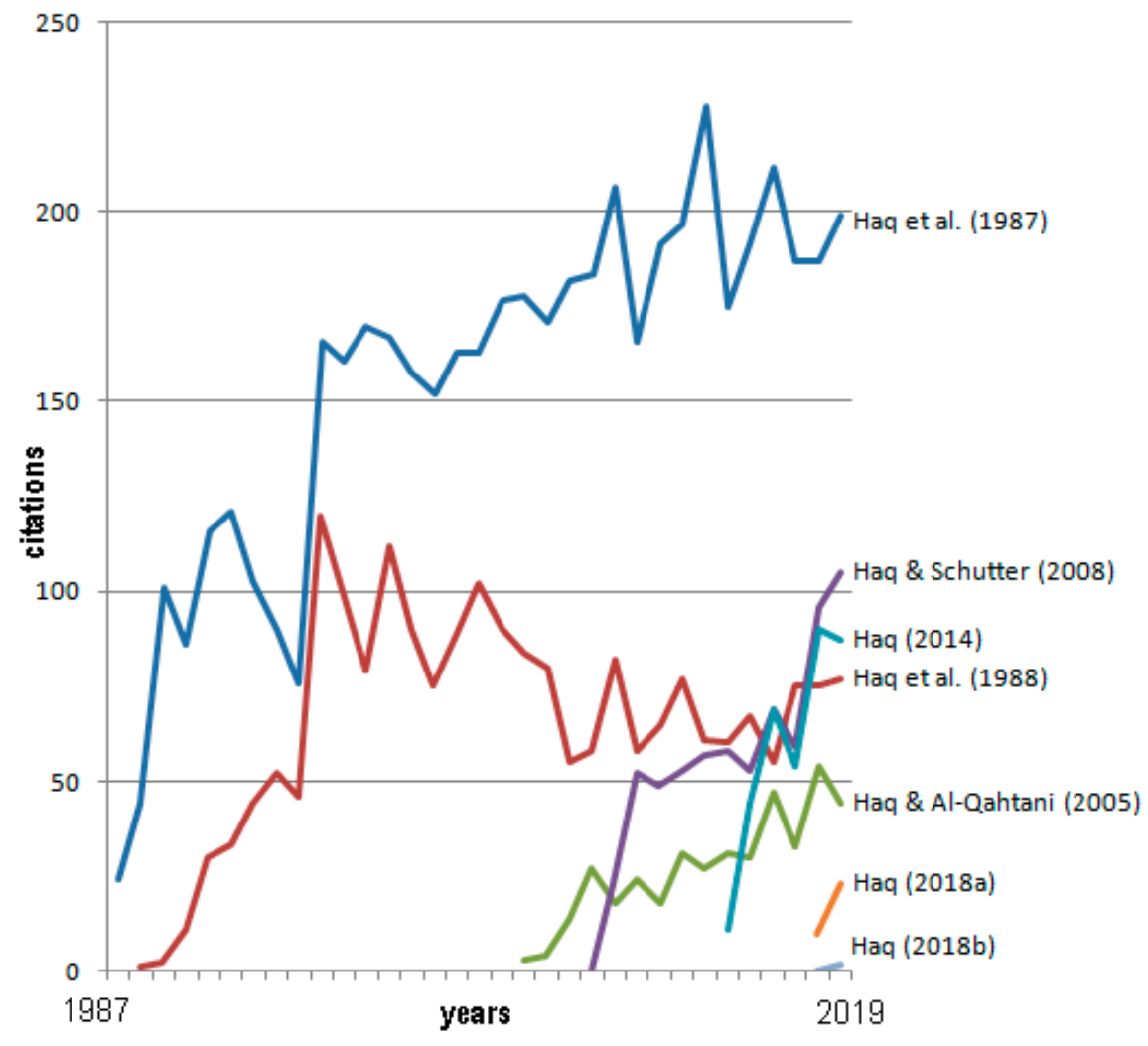

Figure 1. Changes in the number of citations of the eustatic reconstructions by B.U. Haq and his co-workers. 


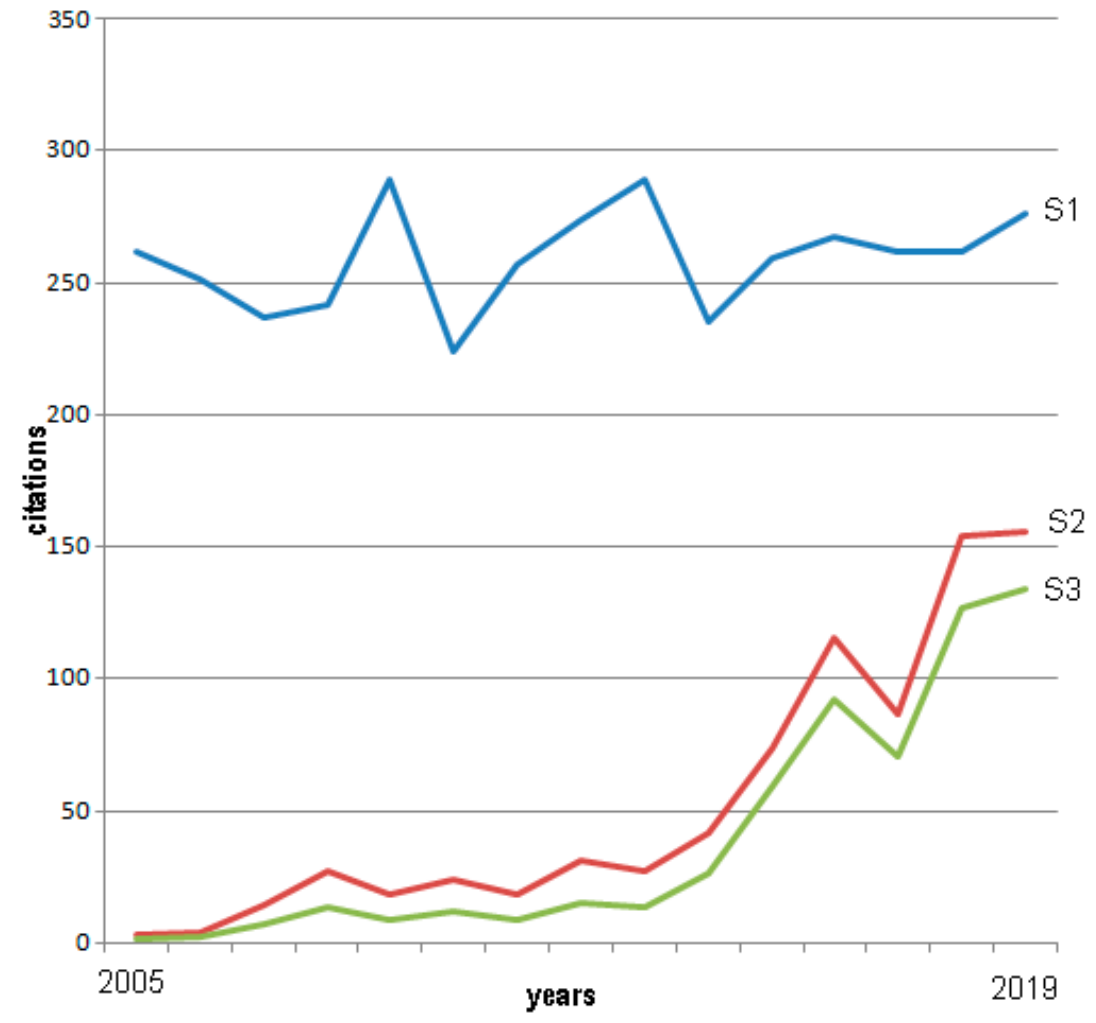

Figure 2. Changes in the number of citations of the considered articles with the Mesozoic-Cenozoic eustatic reconstructions (see text for explanations).

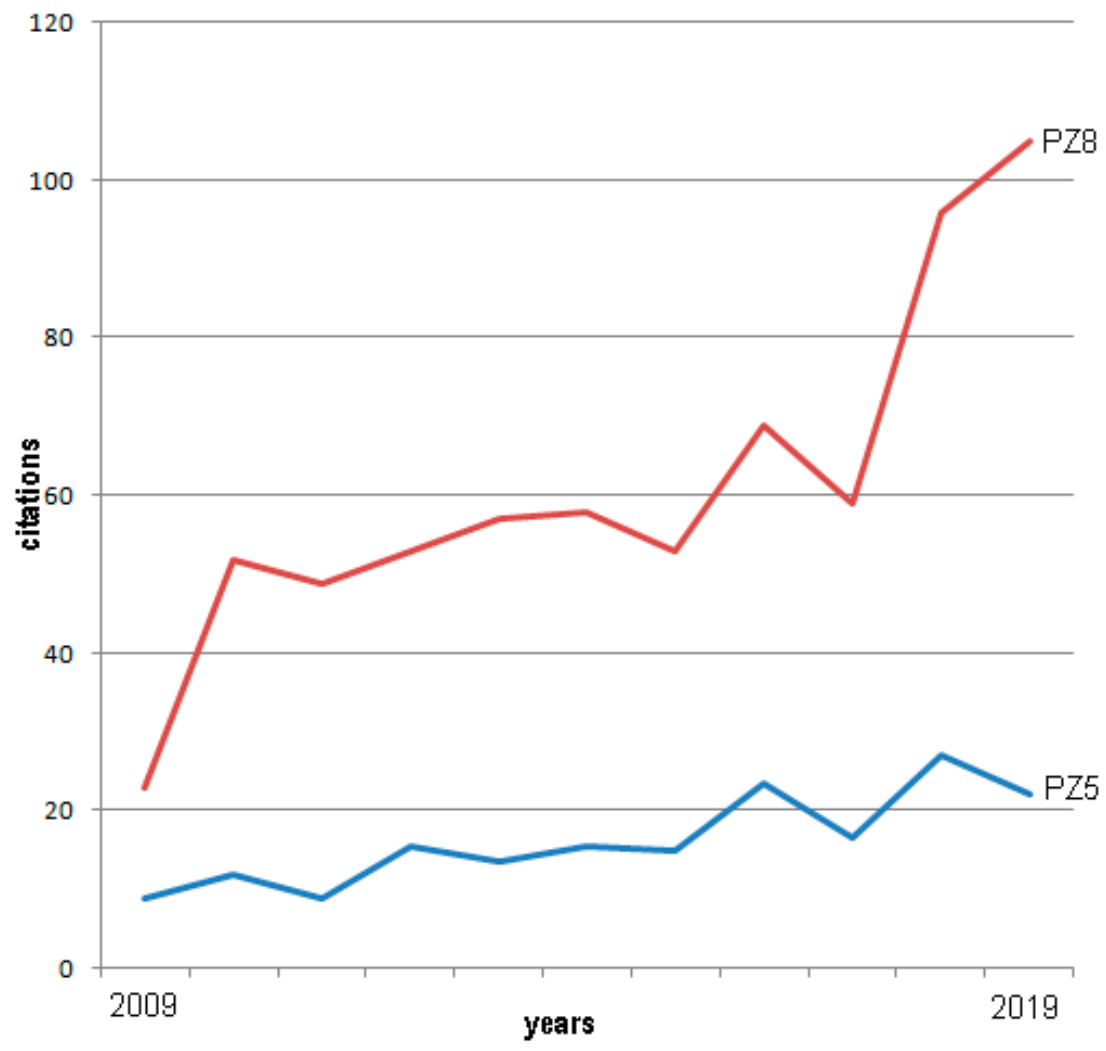

Figure 3. Changes in the number of citationsof the considered articles with the Paleozoic eustatic reconstructions (see text for explanations). 
Of interest is the relative number of the works citing both the 'classical' and updated papers. It is established that the number of papers citing both [23] and [34] is less than $5 \%$ of the total amount of the works citing these papers since 2005 (the year of publication of [34]). Similarly, the number of papers citing both [34] and [35] is 5\% of the total amount of the works citing these papers since 2008 (the year of publication of [35]). These findings reflect the small number of researchers who concern themselves with the very latest update onthe eustatic reconstructions. Interestingly, those preferring the updated reconstructions often do not refer to the earlier works ( $>70 \%$ of the works citing [34] do not refer to [23], and $>90 \%$ of the works citing [35] do not refer to [34]). In rare cases, this can be explained by journal rules limiting the number of references.

The results on citation patterns presented above imply that the research community is aware of the 'fresh' version of the Paleozoic eustatic reconstruction, but it is sufficiently unaware of the updates regarding the Mesozoic-Cenozoic eustatic reconstruction. Even if we were to consider that some geologists cite the works by Haq et al. [23,24] for historical reasons and then use the updated versions [34,36-38] for their research purposes, it is still clear that the number of the articles citing only the 'classical' works is enormously large, and it was even more so until the mid-2010s (see difference between S1 and S2/S3 on Figure 2). One can also suppose that it is a consequence of authors of review-type papers to cite the 'classical' works, but the number of such papers among all papers citing the main work by Haq [23] is less than $4 \%$, and it cannot explain so numerous citations.

Generally, these results signify that authors of hundreds of papers have referred to the outdated eustatic reconstructions and continue todo so. Hundreds of journal reviewers and dozens of editors have not recognized this problem and allowed the accumulation of questionable interpretations based on outdated models. The extraordinarily high degree of unawareness by the entire international geological research community is revealed, and this may have serious consequences. For instance, the use of outstanding eustatic reconstructions for deciphering the stratigraphical record of a given sedimentary basin can lead to a conclusion that the regional sea-level cyclicity and/or its magnitude corresponded well to the global eustatic changes, whereas such a correspondence may be less evident (or absent) when the revised curves are considered. The erroneous interpretations can persist for years and decades until new investigations will be undertaken. Concerning how many papers still refer to the 'classical' curves by Haq et al. [23,24], it appears that a significant portion of current geological knowledge could be based on the outstanding interpretations. Importantly, this portion will only increase, as there is no evidence of any decline in the number of citations of the original works relative to the updated works (Figure 2). Significant unawareness leads to a 'messy' style of research and less reliable conclusions. The situation is much better in regard to the Paleozoic (Figure 3). However, any future update of the curve proposed by Haq and Schutter [35] may result in the same problem registered for the Mesozoic-Cenozoic interval.

\section{Case B: End-Pleistocene Extraterrestrial Impact}

The end-Pleistocene events, including climatic perturbations (Younger Dryas cooling) [39-41] and megafaunal extinctions (disappearance of mammoths, ground sloths, etc.) [42,43] have attracted significant attention of geologists for decades because of their 'sudden' character and unclear causes. A new round of debates began at the end of the 2000s, when Firestone et al. [44] proposed a hypothesis of the end-Pleistocene extraterrestrial impact to explain a chain of the noted events. The first reaction by the research community was somewhat mixed (e.g., [45,46]). The evidence in support of this hypothesis [47-59] and against it [17,40,60-67] accumulated in the following years, and debates have continued despite some attempts to proclaim this hypothesis as 'finally' rejected. From all the relevant literature that continues to grow, three papers seem to be especially important. These are the original (hypothesis proposal) study by Firestone et al. [44], the article by Haynes [45] where he judged the hypothesis to need testing, and the review by Surovell et al. [66], where arguments against this hypothesis were gathered (importantly, Haynes is among the co-authors of the rejection camp). The outstanding character of these papers is underlined by the total number of their citations relative 
to the other publications (350 citations of [44], 153 citations of [45] and 90 citations of [66]). Importantly, these basic papers were published at the end of the 2000s, and the tracking of their citation dynamics allows forthe analysis of the research community's awareness of the hypothesis through the 2010s.

While a hypothesis remains debatable, the research community should be fully aware of the arguments pro et contra. Therefore, the proposal and rejection papers should be cited more or less equally. Alternatively, a kind of unawareness takes place. The results of citation analysis in this case are presented in Figure 4. The article by Firestone et al. [44] gained numerous citations in two years after its publication, which was followed by a decline in the citation rate (nonetheless, it is cited in those papers presenting new research, not only in review-type papers for historical reasons). Much the same pattern occurred with the work by Surovell et al. [66] that marshalled arguments against the hypothesis. Interestingly, the paper by Haynes [45] remained relatively well-citable through the entire 2010s. A comparison of citation dynamics allows three notable inferences. First, the proposal paper was cited more actively than the rejection paper (Figure 4). This can be interpreted as a kind of 'shock' or 'fascination' of the research community by the hypothesis. One can note that a larger number of rejection papers was published [17,40,60-67], i.e., the specialists who wished to consider the hypothesis critically could cite different rejection papers. However, the majority of the latter appeared later, i.e., in the 2010s (add also up to two years for citing them), and, thus, the paper by Surovell et al. [66] remained the main source of arguments against this hypothesis. Second, one can note more active citations of the paper by Haynes [45] containing doubts about the end-Pleistocene extraterrestrial impact scenario, but leaving this hypothesis some chance (in contrast to the later rejection work by Surovell et al. [66], with Haynes as a co-author). This supports evidence of sufficient unawareness by the international research community. Third, the very decline in citations of Firestone et al. [44] and Surovell et al. [66] in the second half of the 2010s (Figure 4) appears to be strange, as the hypothesis has remained neither proven nor disproven, with new evidence appearing each year (e.g., [54,67]). The potential importance of this hypothesis in modern geology remains significant. If proven, it can explain the puzzle of end-Pleistocene environmental perturbations. This situation implies another example of unawareness in the research community, which continues research in the end-Pleistocene events, but 'abstains' from the debatable hypothesis and even 'abandons' the latter.

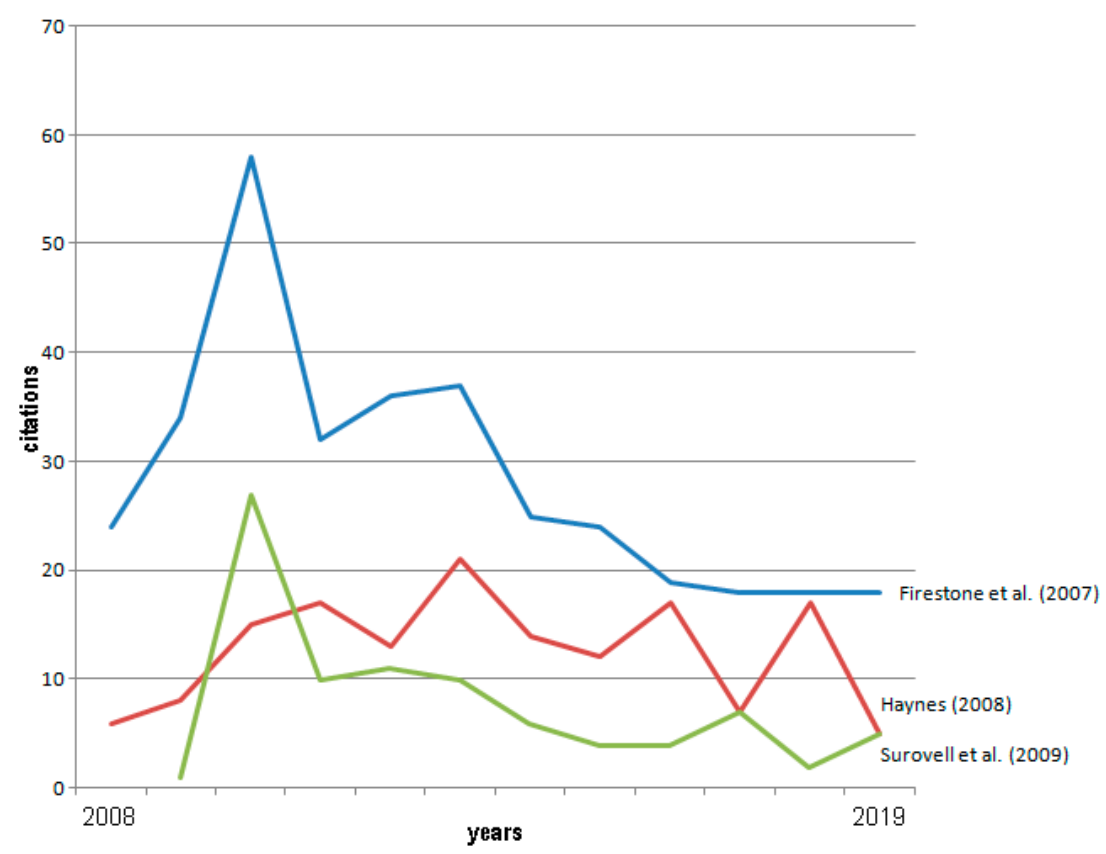

Figure 4. Changes in the number of citations of the basic articles on the end-Pleistocene extraterrestrial impact hypothesis. 
The relative proportion of works citing both the proposal and rejection papers is small. It is $23 \%$ for the sources [44] and [45] (since 2008, when [45] was published), 19\% for the sources [45] and [66] (since 2009, when [66] was published), and 27\% for the sources [44] and [66] (since 2009, when [66] was published). This implies that the very challenge of the previous ideas is relatively rarely addressed.

The information on citations of the basic articles on the end-Pleistocene extraterrestrial impact hypothesis indicates a relative vacuity in the awareness of the international research community. Although both the proposal and rejection papers have been relatively well-cited, it is evident that the hypothesis is not considered by geologists in a balanced way. Many papers that refer to this hypothesis are neutral to its approval or disproval, i.e., the authors mention this hypothesis as nothing more than a notable piece of the knowledge. In this case, it would be reasonable to expect that they cite the basic works with arguments pro et contra. However, citation records show this is not true (Figure 4). This and other kinds of unawareness by the research community (see above) may have serious consequences. In the long-term, critical comments will be judged as more and more 'marginal', the strength of arguments against this hypothesis will be moderated by relatively more frequent consideration of the work where the hypothesis is claimed to be tested, and the gradual 'abandonment' of the hypothesis (although not tested fully) will contribute to the unnecessary accumulation of probabilistic knowledge.

\section{Discussion}

The two examples of unawareness in the research community raise questions as to its origin in modern geology. Apparently, insufficient awareness documented by the citation records sheds light on the problems pertinent to literature gathering, the critical examination of the previous works, and, more generally, theoretical advances in geology. This problem becomes even more evident in the comparison of geological articles with those on social sciences in top international journals. A typical geological research is chiefly fact-based, with significant attention being paid to methodology and novel results (field and laboratory findings). Theoretical considerations play a secondary role. Geological theory includes general knowledge ('textbook knowledge'), reviews of facts, and classifications that are often intuitive. Such an approach makes comprehensive and critical consideration of the literature less important, which leads to the unawareness of some works/ideas as demonstrated by the examples considered in the present paper. The situation is very different in the social sciences. Although empirical research dominates there too, a typical economical or sociological article usually bears not only a synopsis of the previous developments, but also their critical consideration and conceptual treatment. Moreover, literature reviews (to be distinguished from fact reviews) are much demanded by editors and are more frequent in the social sciences $[68,69]$. These factors do not only increase the awareness of the relevant research, but also allow for the systematization of information and generation of new knowledge. For instance, Weinfurtner and Seidl [70] reviewed comprehensively and systematized thematically the previous literature on organizational space management and provided new conceptual models. One should also note the important role of bibliometry-based studies that contribute substantially to the research community's awareness in social sciences (typical examples are [71-73]), as well as 'purely' theoretical works with re-consideration of the previous ideas (e.g., [74,75]). In contemporary geology, similar research also exists, but in subordinate amounts (rare examples include, in particular, the papers by Camargo et al. [76], Chiu and Ho [77], Gizzi [78], Liu et al. [79], Marx and Bornmann [80], and Stead and Wolter [81], as well as some works on sequence stratigraphy [82-84]).

The social sciences differ essentially from geology and other natural sciences, but it appears that the over-dominance of fact-based research without in-depth theorizing stimulates a specific, somewhat 'chaotic' [16] character in scientific progress with growing gaps in the awareness by the research community. It is relevant to add that critical literature reviews, bibliometric analyses, and various theoretical developments are not typical to only social sciences, but these are also very popular in medicine and the environmental sciences. Generally, a shift from geological theory only to theoretical geologyis proposed (Figure 5). Of course, this does not mean less attention is paid to facts, but such a shift would facilitate progress in science via critical literature reviews, bibliometric approaches, 
comparison of the previous results and their updates (not necessarily with involvement of new facts and emphasis on the latter), conceptual classifications, in-depth theoretical treatments, etc. At the least, these factors would diminish unawareness and help promote modern geology to become more diverse. For example, the very fresh update on the Cenozoic eustatic reconstruction by Miller et al. [85] should not be 'missed' by geologists.

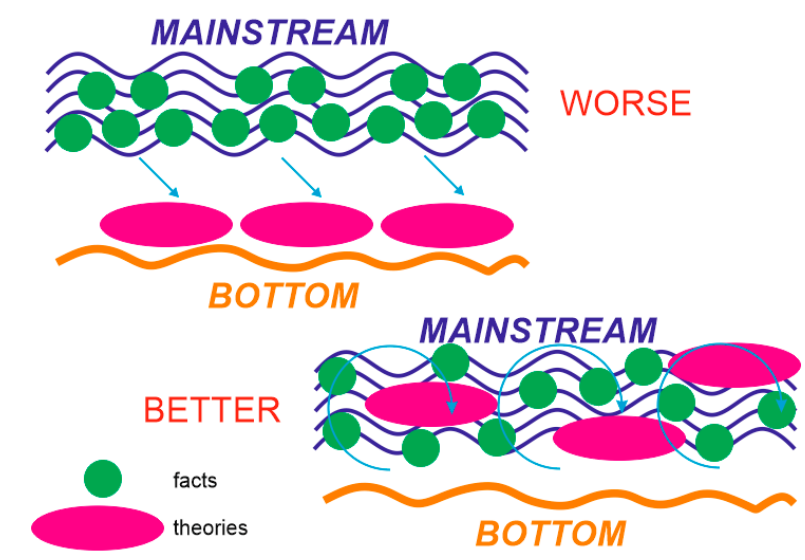

Figure 5. Schematic representation of geology development in conditions of fact over-emphasis (upper drawing) and balanced empirical and theoretical research (lower drawing).

Theoretical geology allows for a normalization of the research community's awareness, as well as to address the negative consequences of unawareness. This can be illustrated with the same two examples considered in the present paper. In case A, the negative consequence is linked to the 'penetration' of the outdated eustatic models into regional studies. In conditions of modern geology, it is necessary to wait until any geologist collects new data in a given region and decides to plot her/his interpretation against the eustatic curve. However, it seems to be much more efficient to not wait for new data, but 'simply' to re-interpret the already published material in the light of the eustatic update. Spreading theoretical geology and the relevant quantitative and qualitative development of research lines (increase in the number of the relevant research projects and publications and deepening of the conceptual treatment of geological information) will allow for the publication of such a study in any international journal. In case B, one consequence of the registered unawareness is hypothesis 'abandonment'. The over-dominance of fact-based research does not leave much chance for hypotheses to be debated over a long time because these do not form are liable basis for factual interpretations. However, a broad theoretic vision opens other ways for the utilization of such hypotheses. On the one hand, the very discussion of the hypotheses brings new geological information (not necessarily related strictly to the hypothesis 'core'), contributes to methodological improvements and innovations, stimulates conceptualization of the knowledge (via clear distinction between hypotheses and theories), and helps to recruit young scientists. On the other hand, all evidence relevant to the end-Pleistocene extraterrestrial impact hypothesis (irrespective of whether this evidence proves or disproves the latter) implies that the end-Pleistocene environments are debated in much the same way as the other critical boundaries in the Phanerozoic (with attention to extreme events-extinctions, impacts, volcanism, climate changes, etc.) $[46,86,87]$ that may be very important to discuss the hierarchical status of the Quaternary, its subdivisions, and the order of the Pleistocene/Holocene boundary due to the formalization of the Anthropocene unit [88-93].

This study bears discussion of yet another issue, namely the relative importance of open-access publications. The 'classical' papers on eustasyby Haq et al. [23,24] and Firestone et al. [44] were published in traditional, subscription-based journals (these appeared before the 'era' of open access). As for the updating and rejection papers (see above), these were published in both subscription-based and open-access editions. Although one can argue that the registered unawareness means that the better accessibility of the newer works does not guarantee their active distribution among the 
international readership, such an interpretation is not plausible in regard to the cases considered in this study. In fact, the 'classical' works are thought to be so important that their free-access versions are available by Internet, and, thus, these do not differ from the papers published in the open-access editions. The appearance of 'classical' works in prestige journals with high impact factor 'equates' their accessibility to the papers in the open-access editions.

\section{Conclusions}

The present study permits some tentative insights into the problem of unawareness within the modern geological research community. Three main conclusions are as follows:(1) many geologists are unaware of updates regarding the famous Mesozoic-Cenozoic eustatic reconstructions; (2) the arguments pro et contra of the end-Pleistocene extraterrestrial impact hypothesis are cited disproportionally; (3) some deficit of awareness of literature and ideas can be linked to problems with theorizing in modern geology (especially in comparison to social sciences). More generally, the citation analysis undertaken herein regarding some landmark papers demonstrates that scientific cognition and progress in modern geology fails to avoid serious deficiencies. The noted unawareness of knowledge updates and important ideas rooted in 'marginalized' theorizing drives the science in a harmful way and, at least, produces some amount of questionable, 'chaotic' knowledge. Geologists need to look to the literature on social sciences in order to learn how to escape many pitfalls in the progress of their own science.

The observations and the thoughts presented in this paper are preliminary because of three limitations. First, only two examples are considered. Second, only relatively simple citation analysis is undertaken. Further research should explore geographical and by-journal distribution of citations. This may provide a lot of interesting insights, although, most probably, the results of such analyses will show an even greater unawareness of the international research community. Third, the opinion of geologists should be investigated with questionnaires, interviews, etc. (the relevant methodologies need development in the future). The less completeness of the 'Scopus' database for the years before the mid-2000s is not a serious limitation to the present citation analysis because significant unawareness was registered also for the 2000s and the 2010s. In any case, the results of the present study imply that the problem of the research community unawareness in the contemporary geology is very significant, and its solution may require serious reconsideration of widely practiced research patterns. Moreover, even such preliminary observations and thoughts recommend to geologists, including those selected as reviewers and serving as journal editors, that greater attention be paid to the previous research and publications. This applies, as well, to caution in the avoidance of theory-based in geological investigations.

Funding: This research received no external funding.

Acknowledgments: The author thanks the journal's editorial team and all four reviewers for their valuable recommendations and support, as well as M.E. Johnson (USA) for his polishing of this paper and O.V. Dudnikova (Russia) for her permanent library assistance.

Conflicts of Interest: The author declares no conflict of interest.

\section{References}

1. Feenberg, A. Critical theory of technology and STS. Thesis Elev. 2017, 138, 3-12. [CrossRef]

2. Hess, D.J. Neoliberalism and the History of STS Theory: Toward a Reflexive Sociology. Soc. Epistemol. 2013, 27, 177-193. [CrossRef]

3. Kihara, H. The Neoliberal Transformation of STS in Japan. A J. Knowl. Cult. Policy 2013, 27, 145-162. [CrossRef]

4. Matsumoto, M. Theoretical challenges for the current sociology of science and technology: A prospect for its future development. East Asian Sci. Technol. Soc. 2010, 4, 129-136. [CrossRef]

5. Nakajima, H. STS Towards the Twenty-first Century. Sci. Technol. Soc. 1999, 4, 55-58. [CrossRef] 
6. Ogg, J.G.; Ogg, G.M.; Gradstein, F.M. A Concise Geologic Time Scale 2016; Elsevier: Amsterdam, The Netherlands, 2016.

7. Ruban, D.A. Geologic time scales in modern books: A failure of standardization? Proc. Geol. Assoc. 2011, 122, 347-353. [CrossRef]

8. Alvarez, W.T. The story that waited 65 million years to be told-How a giant impact killed the dinosaurs, and how the crater was discovered. In Rex and the Crater of Doom; Princeton University Press: Princeton, NJ, USA, 2008.

9. Alvarez, L.W.; Alvarez, W.; Asaro, F.; Michel, H.V. Extraterrestrial cause for the Cretaceous-Tertiary extinction. Science 1980, 208, 1095-1108. [CrossRef]

10. Courtillot, V. Evolutionary Catastrophes-The Science of Mass Extinction; Cambridge University Press: Cambridge, UK, 2007.

11. Hull, P.M.; Bornemann, A.; Penman, D.E.; Henehan, M.J.; Norris, R.D.; Wilson, P.A.; Blum, P.; Alegret, L.; Batenburg, S.J.; Bown, P.R.; et al. On impact and volcanism across the Cretaceous-Paleogene boundary. Science 2020, 367, 266-272. [CrossRef]

12. Keller, G. Biotic effects of impacts and volcanism. Earth Planet. Sci. Lett. 2003, 215, 249-264. [CrossRef]

13. Schoene, B.; Eddy, M.P.; Samperton, K.M.; Keller, C.B.; Keller, G.; Adatte, T.; Khadri, S.F.R. U-Pb constraints on pulsed eruption of the Deccan Traps across the end-Cretaceous mass extinction. Science 2019, 363, 862-866. [CrossRef]

14. Schulte, P.; Alegret, L.; Arenillas, I.; Arz, J.A.; Barton, P.J.; Bown, P.R.; Bralower, T.J.; Christeson, G.L.; Claeys, P.; Cockell, C.S.; et al. The Chicxulub asteroid impact and mass extinction at the Cretaceous-Paleogene boundary. Science 2010, 327, 1214-1218. [CrossRef] [PubMed]

15. Prothero, D.L. Greenhouse Of The Dinosaurs: Evolution, Extinction, and the Future of Our Planet; Columbia University Press: New York, NY, USA, 2009.

16. Ruban, D.A. A "chaos" of Phanerozoic eustatic curves. J. Afr. Earth Sci. 2016, 116, 225-232. [CrossRef]

17. Van Hoesel, A.; Hoek, W.Z.; Pennock, G.M.; Drury, M.R. The Younger Dryas impact hypothesis: A critical review. Quat. Sci. Rev. 2014, 83, 95-114. [CrossRef]

18. Franssen, T.; Wouters, P. Science and its significant other: Representing the humanities in bibliometric scholarship. J. Assoc. Inf. Sci. Technol. 2019, 70, 1124-1137. [CrossRef]

19. Gerdel, W. Scope, methods and results of scientometry and bibliometry for planning and research. Methods Inf. Med. 1976, 15, 259-261.

20. Giske, J. Benefitting from bibliometry. Ethics Sci. Environ. Politics 2008, 8, 79-81. [CrossRef]

21. Motoyama, Y.; Eisler, M.N. Bibliometry and nanotechnology: A meta-analysis. Technol. Forecast. Soc. Chang. 2011, 78, 1174-1182. [CrossRef]

22. Prashar, A.; Sunder, M.V. A bibliometric and content analysis of sustainable development in small and medium-sized enterprises. J. Clean. Prod. 2020, 245, 118665. [CrossRef]

23. Haq, B.U.; Hardenbol, J.; Vail, P.R. Chronology of fluctuating sea levels since the Triassic. Science 1987, 235, 1156-1167. [CrossRef]

24. Haq, B.U.; Hardenbol, J.; Vail, P.R. Mesozoic and Cenozoic chronostratigraphy and cycles of sea-level change. Sepm Spec. Publ. 1988, 42, 71-108.

25. Abreu, V.S.; Anderson, J.B. Glacial eustasy during the Cenozoic: Sequence stratigraphic implications. Aapg Bull. 1998, 82, 1385-1400.

26. Cao, W.; Flament, N.; Zahirovic, S.; Williams, S.; Müller, R.D. The interplay of dynamic topography and eustasy on continental flooding in the late Paleozoic. Tectonophysics 2019, 761, 108-121. [CrossRef]

27. Hallam, A. Pre-Quaternary sea-level changes (Phanerozoic eustasy). Annu. Rev. Earth Planet. Sci. 1984, 12, 205-244. [CrossRef]

28. Hallam, A. A reevaluation of Jurassic eustasy in the light of new data and the revised Exxon curve. Sepm Spec. Publ. 1988, 42, 261-273.

29. Hallam, A. A review of the broad pattern of Jurassic sea-level changes and their possible causes in the light of current knowledge. Palaeogeogr. Palaeoclimatol. Palaeoecol. 2001, 167, 23-37. [CrossRef]

30. Kominz, M.A.; Browning, J.V.; Miller, K.G.; Sugarman, P.J.; Mizintseva, S.; Scotese, C.R. Late Cretaceous to Miocene sea-level estimates from the New Jersey and Delaware coastal plain coreholes: An error analysis. Basin Res. 2008, 20, 211-226. [CrossRef] 
31. Miller, K.G.; Kominz, M.A.; Browning, J.V.; Wright, J.D.; Mountain, G.S.; Katz, M.E.; Sugarman, P.J.; Cramer, B.S.; Christie-Blick, N.; Pekar, S.F. The Phanerozoic record of global sea-level change. Science 2005, 310, 1293-1298. [CrossRef] [PubMed]

32. Müller, R.D.; Sdrolias, M.; Gaina, C.; Steinberger, B.; Heine, C. Long-term sea-level fluctuations driven by ocean basin dynamics. Science 2008, 319, 1357-1362. [CrossRef]

33. Ruban, D.A.; Zorina, S.O.; Conrad, C.P.; Afanasieva, N.I. In quest of Paleocene global-scale transgressions and regressions: Constraints from a synthesis of regional trends. Proc. Geol. Assoc. 2012, 123, 7-18. [CrossRef]

34. Haq, B.U.; Al-Qahtani, A.M. Phanerozoic cycles of sea-level change on the Arabian platform. GeoArabia 2005, 10, 127-160.

35. Haq, B.U.; Schutter, S.R. A chronology of Paleozoic sea-level changes. Science 2008, 322, 64-68. [CrossRef] [PubMed]

36. Haq, B.U. Cretaceous eustasy revisited. Glob. Planet. Chang. 2014, 113, 44-58. [CrossRef]

37. Haq, B.U. Jurassic sea-level variations: A reappraisal. GSA Today 2018, 28, 4-10. [CrossRef]

38. Haq, B.U. Triassic eustatic variations reexamined. GSA Today 2018, 28, 4-9. [CrossRef]

39. Bakke, J.; Lie, O.; Heegaard, E.; Dokken, T.; Haug, G.H.; Birks, H.H.; Dulski, P.; Nilsen, T. Rapid oceanic and atmospheric changes during the Younger Dryas cold period. Nat. Geosci. 2009, 2, 202-205. [CrossRef]

40. Broecker, W.S.; Denton, G.H.; Edwards, R.L.; Cheng, H.; Alley, R.B.; Putnam, A.E. Putting the Younger Dryas cold event into context. Quat. Sci. Rev. 2010, 29, 1078-1081. [CrossRef]

41. Mayewski, P.A.; Meeker, L.D.; Whitlow, S.; Twickler, M.S.; Morrison, M.C.; Alley, R.B.; Bloomfield, P.; Taylor, K. The atmosphere during the Younger Dryas. Science 1993, 261, 195-197. [CrossRef]

42. Martin, P.S. Twilight of the Mammoths: Ice Age Extinctions and the Rewilding of America; University of California Press: Berkeley, CA, USA, 2005.

43. Stuart, A.J. Late Quaternary megafaunal extinctions on the continents: A short review. Geol. J. 2015, 50, 338-363. [CrossRef]

44. Firestone, R.B.; West, A.; Kennett, J.P.; Becker, L.; Bunch, T.E.; Revay, Z.S.; Schultz, P.H.; Belgya, T.; Kennett, D.J.; Erlandson, J.M.; et al. Evidence for an extraterrestrial impact 12,900 years ago that contributed to the megafaunal extinctions and the Younger Dryas cooling. Proc. Natl. Acad. Sci. USA 2007, 104, 16016-16021. [CrossRef]

45. Haynes, C.V., Jr. V. Younger Dryas "black mats" and the Rancholabrean termination in North America. Proc. Natl. Acad. Sci. USA 2008, 105, 6520-6525. [CrossRef]

46. Ruban, D.A. The survival of megafauna after the end-Pleistocene impact: A lesson from the Cretaceous/Tertiary boundary. Geologos 2009, 15, 129-132.

47. Bunch, T.E.; West, A.; Firestone, R.B.; Kennett, J.P.; Wittke, J.H.; Kinzie, C.R.; Wolbach, W.S. Geochemical data reported by Paquay et al. do not refute Younger Dryas impact event. Proc. Natl. Acad. Sci. USA 2010, 107, E58. [CrossRef]

48. Firestone, R.B.; West, A.; Bunch, T.E. Confirmation of the Younger Dryas boundary (YDB) data at Murray Springs, AZ. Proc. Natl. Acad. Sci. USA 2010, 107, E105. [CrossRef]

49. Hagstrum, J.T.; Firestone, R.B.; West, A.; Weaver, J.C.; Bunch, T.E. Impact-related microspherules in Late Pleistocene Alaskan and Yukon "muck" deposits signify recurrent episodes of catastrophic emplacement. Sci. Rep. 2017, 7, 16620. [CrossRef]

50. Israde-Alcántara, I.; Bischoff, J.L.; Domínguez-Vázquez, G.; Li, H.-C.; DeCarli, P.S.; Bunch, T.E.; Wittke, J.H.; Weaver, J.C.; Firestone, R.B.; West, A.; et al. Evidence from Central Mexico supporting the Younger Dryas extraterrestrial impact hypothesis. Proc. Natl. Acad. Sci. USA 2012, 109, E738-E747. [CrossRef]

51. Kennett, J.P.; Kennett, D.J.; Culleton, B.J.; Tortosa, J.E.A.; Bischoff, J.L.; Bunch, T.E.; Daniel, I.R., Jr.; Erlandson, J.M.; Ferraro, D.; Firestone, R.B.; et al. Bayesian chronological analyses consistent with synchronous age of 12,835-12,735 Cal B.P. for Younger Dryas boundary on four continents. Proc. Natl. Acad. Sci. USA 2015, 112, E4344-E4353. [CrossRef]

52. Kinzie, C.R.; Hee, S.S.Q.; Stich, A.; Tague, K.A.; Mercer, C.; Razink, J.J.; Kennett, D.J.; DeCarli, P.S.; Bunch, T.E.; Wittke, J.H.; et al. Nanodiamond-rich layer across three continents consistent with major cosmic impact at 12,800 cal BP. J. Geol. 2014, 122, 475-506. [CrossRef]

53. Mahaney, W.C.; Keiser, L.; Krinsley, D.; Kalm, V.; Beukens, R.; West, A. New evidence from a black mat site in the Northern Andes supporting a cosmic impact 12,800 years ago. J. Geol. 2013, 121, 309-325. [CrossRef] 
54. Moore, A.M.T.; Kennett, J.P.; Napier, W.M.; Bunch, T.E.; Weaver, J.C.; LeCompte, M.; Adedeji, A.V.; Hackley, P.; Kletetschka, G.; Hermes, R.E.; et al. Evidence of Cosmic Impact at Abu Hureyra, Syria at the Younger Dryas Onset $(\sim 12.8 \mathrm{ka})$ : High-temperature melting at $>2200{ }^{\circ} \mathrm{C}$. Sci. Rep. 2020, 10, 4185. [CrossRef]

55. Napier, W.M. The hazard from fragmenting comets. Mon. Not. R. Astron. Soc. 2019, 488, $1822-1827$. [CrossRef]

56. Pino, M.; Abarzúa, A.M.; Astorga, G.; Martel-Cea, A.; Cossio-Montecinos, N.; Navarro, R.X.; Lira, M.P.; Labarca, R.; LeCompte, M.A.; Adedeji, V.; et al. Sedimentary record from Patagonia, southern Chile supports cosmic-impact triggering of biomass burning, climate change, and megafaunal extinctions at $12.8 \mathrm{ka}$. Sci. Rep. 2019, 9, 4413. [CrossRef]

57. Wittke, J.H.; Weaver, J.C.; Bunch, T.E.; Kennett, J.P.; Kennett, D.J.; Moore, A.M.T.; Hillman, G.C.; Tankersley, K.B.; Goodyear, A.C.; Moore, C.R.; et al. Evidence for deposition of 10 million tonnes of impact spherules across four continents 12,800 y ago. Proc. Natl. Acad. Sci. USA 2013, 110, E2088-E2097. [CrossRef]

58. Wolbach, W.S.; Ballard, J.P.; Mayewski, P.A.; Adedeji, V.; Bunch, T.E.; Firestone, R.B.; French, T.A.; Howard, G.A.; Israde-Alcántara, I.; Johnson, J.R.; et al. Extraordinary biomass-burning episode and impact winter triggered by the Younger Dryas cosmic impact $\sim 12,800$ years ago. 1 . Ice cores and glaciers. J. Geol. 2018, 126, 165-184. [CrossRef]

59. Wolbach, W.S.; Ballard, J.P.; Mayewski, P.A.; Parnell, A.C.; Cahill, N.; Adedeji, V.; Bunch, T.E.; Domínguez-Vázquez, G.; Erlandson, J.M.; Firestone, R.B.; et al. Extraordinary biomass-burning episode and impact winter triggered by the Younger Dryas cosmic impact $\sim 12,800$ years ago. 2. Lake, marine, and terrestrial sediments. J. Geol. 2018, 126, 185-205. [CrossRef]

60. Bement, L.C.; Madden, A.S.; Carter, B.J.; Simms, A.R.; Swindle, A.L.; Alexander, H.M.; Fine, S.; Benamara, M. Quantifying the distribution of nanodiamonds in pre-Younger Dryas to recent age deposits along Bull Creek, Oklahoma Panhandle, USA. Proc. Natl. Acad. Sci. USA 2014, 111, 1726-1731. [CrossRef]

61. Boslough, M.; Harris, A.W.; Chapman, C.; Morrison, D. Younger Dryas impact model confuses comet facts, defies airburst physics. Proc. Natl. Acad. Sci. USA 2013, 110, E4170. [CrossRef]

62. Daulton, T.L.; Amari, S.; Scott, A.C.; Hardiman, M.; Pinter, N.; Anderson, R.S. Comprehensive analysis of nanodiamond evidence relating to the Younger Dryas Impact Hypothesis. J. Quat. Sci. 2017, 32, 7-34. [CrossRef]

63. Holliday, V.T.; Surovell, T.; Meltzer, D.J.; Grayson, D.K.; Boslough, M. The Younger Dryas impact hypothesis: A cosmic catastrophe. J. Quat. Sci. 2014, 29, 515-530. [CrossRef]

64. Pinter, N.; Ishman, S.E. Impacts, mega-tsunami, and other extraordinary claims. Gsa Today 2008, $18,37$. [CrossRef]

65. Scott, A.C.; Pinter, N.; Collinson, M.E.; Hardiman, M.; Anderson, R.S.; Brain, A.P.R.; Smith, S.Y.; Marone, F.; Stampanoni, M. Fungus, not comet or catastrophe, accounts for carbonaceous spherules in the Younger Dryas "impact layer". Geophys. Res. Lett. 2016, 37, L14302. [CrossRef]

66. Surovell, T.A.; Holliday, V.T.; Gingerich, J.A.M.; Ketron, C.; Haynes, C.V., Jr.; Hilman, I.; Wagner, D.P.; Johnson, E.; Claeys, P. An independent evaluation of the Younger Dryas extraterrestrial impact hypothesis. Proc. Natl. Acad. Sci. USA 2009, 106, 18155-18158. [CrossRef]

67. Van Hoesel, A.; Hoek, W.Z.; Pennock, G.M.; Kaiser, K.; Plümper, O.; Jankowski, M.; Hamers, M.F.; Schlaak, N.; Küster, M.; Andronikov, A.V.; et al. A search for shocked quartz grains in the Allerød-Younger Dryas boundary layer. Meteorit. Planet. Sci. 2015, 50, 483-498. [CrossRef]

68. Fernandez, K.V. Critically reviewing literature: A tutorial for new researchers. Australas. Mark. J. 2019, 27, 187-196. [CrossRef]

69. Snyder, H. Literature review as a research methodology: An overview and guidelines. J. Bus. Res. 2019, 104, 333-339. [CrossRef]

70. Weinfurtner, T.; Seidl, D. Towards a spatial perspective: An integrative review of research on organisational space. Scand. J. Manag. 2019, 35, 101009. [CrossRef]

71. López-Duarte, C.; Vidal-Suárez, M.M.; González-Díaz, B. Expatriate management and national culture: A bibliometric study of prolific, productive, and most cited authors and institutions. Int. J. Hum. Resour. Manag. 2020, 31, 805-833. [CrossRef]

72. Ramona, O.; Cristina, M.S.; Raluca, S. Bitcoin in the scientific literature-A bibliometric study. Stud. Bus. Econ. 2020, 14, 160-174. [CrossRef] 
73. Wen, D.; Sun, X.; Liu, Y. Bibliometric analysis of supplier management: The theme and cluster perspectives. Sustainability 2020, 12, 2572. [CrossRef]

74. Renda, C. Some Thoughts on Emotional Atmospheres as a Category of Situational Sociology. Koln. Z. Für Soziologie Und Soz. 2018, 70, 629-654. [CrossRef]

75. Rusu, M.S. Theorising love in sociological thought: Classical contributions to a sociology of love. J. Class. Sociol. 2018, 18, 3-20. [CrossRef]

76. Camargo, J.M.R.; Silva, M.V.B.; Júnior, A.V.F.; Araújo, T.C.M. Marine geohazards: A bibliometric-based review. Geosciences 2019, 9, 100. [CrossRef]

77. Chiu, W.T.; Ho, Y.S. Bibliometric analysis of tsunami research. Scientometrics 2007, 73, 3-17. [CrossRef]

78. Gizzi, F.T. Worldwide trends in research on the San Andreas Fault System. Arab. J. Geosci. 2015, 8, 10893-10909. [CrossRef]

79. Liu, X.; Zhan, F.B.; Hong, S.; Niu, B.; Liu, Y. A bibliometric study of earthquake research: 1900-2010. Scientometrics 2012, 92, 747-765. [CrossRef]

80. Marx, W.; Bornmann, L. The emergence of plate tectonics and the Kuhnian model of a paradigm shift: A bibliometric case study based on the Anna Karenina principle. Scientometrics 2013, 94, 595-614. [CrossRef]

81. Stead, D.; Wolter, A. A critical review of rock slope failure mechanisms: The importance of structural geology. J. Struct. Geol. 2015, 74, 1-23. [CrossRef]

82. Catuneanu, O. Sequence stratigraphy in the context of the 'modeling revolution'. Mar. Pet. Geol. 2020, 116, 104309. [CrossRef]

83. Nurgalieva, N.G.; Vinokurov, V.M.; Nurgaliev, D.K. The Golovkinsky strata formation model, basic facies law and sequence stratigraphy concept: Historical sources and relations. Russ. J. Earth Sci. 2007, 9, ES1003. [CrossRef]

84. Qayyum, F.; Betzler, C.; Catuneanu, O. The Wheeler diagram, flattening theory, and time. Mar. Pet. Geol. 2017, 86, 1417-1430. [CrossRef]

85. Miller, K.G.; Browning, J.V.; Schmelz, W.J.; Kopp, R.E.; Mountain, G.S.; Wright, J.D. Cenozoic sea-level and cryospheric evolution from deep-sea geochemical and continental margin records. Sci. Adv. 2020, 6, eaaz1346. [CrossRef]

86. Elewa, A.M.T.; Abdelhady, A.A. Past, present, and future mass extinctions. J. Afr. Earth Sci. 2020, 162, 103678. [CrossRef]

87. Ruban, D.A. A possible contribution of volcanism to the end-Pleistocene megafaunal extinction. Nat. Nascosta 2009, 39, 26-32.

88. Gibbard, P.L.; Lewin, J. Partitioning the Quaternary. Quat. Sci. Rev. 2016, 151, 127-139. [CrossRef]

89. Head, M.J. Formal subdivision of the Quaternary System/Period: Present status and future directions. Quat. Int. 2019, 500, 32-51. [CrossRef]

90. Lanata, J.L.; Briones, C.; Monjeau, A. The Anthropocene controversy as opportunity: A matter of approaches rather than formal designations. Interciencia 2017, 42, 186-189.

91. Nikolov, T.; Hristova, R. Anthropocene versus Holocene in the light of the principles of stratigraphy. Comptes Rendus De L'academie Bulg. Des Sci. 2020, 73, 236-243.

92. Ruddiman, W.F. Three flaws in defining a formal 'Anthropocene'. Prog. Phys. Geogr. 2018, 42, $451-461$. [CrossRef]

93. Smith, F.A.; Elliott Smith, R.E.; Lyons, S.K.; Payne, J.L.; Villaseñor, A. The accelerating influence of humans on mammalian macroecological patterns over the late Quaternary. Quat. Sci. Rev. 2019, 211, 1-16. [CrossRef]

(C) 2020 by the author. Licensee MDPI, Basel, Switzerland. This article is an open access article distributed under the terms and conditions of the Creative Commons Attribution (CC BY) license (http://creativecommons.org/licenses/by/4.0/). 